\title{
Antioxidation Effect of Leg Bone Extracts and Enzyme Hydrolysates from Jeju Crossbred Horses (Jeju Native HorsexThoroughbred)
}

\author{
Dongwook Kim', Jae-In Pak', Hyun-Seok Chae ${ }^{2}$, Young-Boong Kim³ and Aera Jang ${ }^{1}{ }^{*}$ \\ ${ }^{1}$ Department of Animal Products and Food Science, Kangwon National University, Chuncheon 200-701, Korea \\ ${ }^{2}$ National Institute of Animal Science, RDA, Jeju 690-150, Korea \\ ${ }^{3}$ Korea Food Research Institute, Sungnam 463-746, Korea
}

Received August 7, 2013 /Revised September 18, 2013 /Accepted September 23, 2013

\begin{abstract}
This study was conducted to evaluate the antioxidation activity of Jeju crossbred horse (Jeju native horse $\times$ thoroughbred) leg bone extracts (HLBE) and its enzyme hydrolysates by determination of 1,1-diphenyl-2picryl-hydrazyl (DPPH), 2,2-azino-bis(3-ethylbenzo thiazoline-6-sulfonic acid) diammonium salt (ABTS) radical scavenging activity, ferric reducing/antioxidant power (FRAP), and oxygen radical absorbance capacity (ORAC). HLBE was extracted with hot water for $24 \mathrm{hr}$ and lyophilized. The lyophilized HLBE was hydrolyzed using multifect PR6L (MP), pepsin (PS), and a pepsin and pancreatin mixture (PSPC) for $4 \mathrm{hr}$ at 60,50 , and $50^{\circ} \mathrm{C}$, respectively. The hydrolysates were separated by a molecular weight of $3 \mathrm{kDa}$ more or less. When the yield of HLBE was $100 \%$, the yield of hydrolysates less than $3 \mathrm{kDa}$ of MP, PS, and PSPC was 10.86, 3.26, and 8.00\%, respectively. Enzyme hydrolysates with low molecular weight less than $3 \mathrm{kDa}$ in MP and PSPC showed significantly higher DPPH, ABTS radical scavenging activity, and ORAC compared to HLBE and its hydrolysates with more than $3 \mathrm{kDa}$. However, the FRAP of the hydrolysates less than $3 \mathrm{kDa}$ in PS was significantly higher than in MP. These results suggest that low molecular weight enzyme hydrolysates less than $3 \mathrm{kDa}$ have more powerful antioxidation activity, especially when they are hydrolyzed by MP and PSPC rather than PS. Therefore, low molecular weight enzyme hydrolysates of HLBE hydrolyzed with MP and PSPC have significant potential as antioxidants in the food industry. Further in vivo studies are required to support the antioxidation activities of the hydrolysates in vitro.
\end{abstract}

Key words : Jeju crossbred horse, bone, anti-oxidation, hydrolysates, scavenging activity

\section{서 론}

최근 식생활 패턴의 변화, 영양상태의 개선 및 의학의 발달 과 더불어 식품을 이용하여 노화를 지연시키기 위해 항산화 기능성 식품을 섭취하면서 건강을 관리하려는 시도가 많이 이루어지고 있다. 활성산소는 강한 산화력이 있어 인체 내에 서 제거되지 못하면 산화적 스트레스를 유발하게 되며[1], 세 포막 분해, DNA 합성 억제, 단백질 분해, 지방산화 등 생체 내에서 심각한 생리적 장애를 유발하는 것으로 알려져 있다 [2]. 이에 활성산소를 조절할 수 있는 물질로 알려진 항산화제 개발 연구가 활발히 진행되고 있을 뿐만 아니라, 섭취 시 안전 하면서도 흡수가 잘되고 합성 약물이 갖는 부작용을 감소시키 는 기능을 가지고 있는 천연 저분자 항산화 펩타이드에 대한

\footnotetext{
*Corresponding author

Tel : +82-33-250-8643, Fax : +82-33-251-7719

E-mail : ajang@kangwon.ac.kr

This is an Open-Access article distributed under the terms of the Creative Commons Attribution Non-Commercial License (http://creativecommons.org/licenses/by-nc/3.0) which permits unrestricted non-commercial use, distribution, and reproduction in any medium, provided the original work is properly cited.
}

관심이 증가하고 있다[27].

말은 우리나라에서 일반적으로 승용(乘用), 태용(駄用), 만 용(輓用), 식용(食用) 등의 목적으로 사용되어 왔으며 일부 유 럽국가와 일본에서 식용으로 소비되고 있다[22]. 민간요법에 의하면 말은 주로 기억력 감퇴, 건망증, 치매, 신경통, 관절염, 골다공증에 좋다고 알려져 있어서 말고기, 말뼈 분말, 엑기스, 환등의 제품으로 제조되어 시판되고 있으나 이에 대한 연구는 주로 제주마육 사양 및 생산[18], 말고기의 영양 및 식육가치 $[16,28]$, 유전특성[15], 번식에 관한 연구[6]가 주로 진행되어 왔다. 말의 뼈는 국내에 흔히 사용되지는 않지만 인터넷 시장 혹은 제주지역에서 민간요법으로 소비되고 있다. 한의학에서 도 말의 빼가 의약소재로 사용되어 왔는데 “중화본초"에서는 말의 뼈가 성질이 달고 차며 “동의보감"에서도 신경통, 관절 염, 이명 등에 효과가 있고 말의 머리뼈는 머리와 귀에 생긴 염증을 제어한다고 제시되어 있다[19]. 그러나 최근 말의 뼈를 이용한 연구는 그리 많지 않으나 현재까지 보고된 말뼈의 효 능은 36개월령의 숫말의 넙적다리 뼈를 분쇄하여 $50 \%$ 의 아세 톤을 이용하여 추출한 시료의 급여가 성장기 흰쥐의 성장판의 길이와 장골길이를 유의적으로 증가시키고 말빼의 무기물 함 량이 칼슘과 인의 비율이 2:1로서 골대사에 바람직한 영향을 주는 이상적인 비율을 갖고 있음이 보고되었다[19]. 또한 말뼈 
추출물을 폐경기 골다공증 흰쥐에 급여 후 골다공증 개선이 되었음을 보고되었다[22]. 이렇듯 말뼈와 관련된 연구는 주로 골다공증, 빼 성장 등에 관한 것이고 말빼추출물과 저분자의 효소분해물의 항산화 기능에 대한 연구는 미흡한 실정이다. 이에 본 연구에서는 시중 유통되는 제주산 마(한라마) 사골 열수 추출물을 식품 효소를 이용하여 저분자화하였고 저분자 추출물의 항산화 기능을 확인하기 위해 실시하였다.

\section{재료 및 방법}

\section{실험재료}

말뼈는 제주 재래마와 더러브렛(Thoroughbred)종 사이의 교잡종인 제주산 마(한라마)의 뒷 다리뼈를 (주)청정해에서 구 입하여 이용하였다. 1,1-diphenyl-2picryl-hydrazyl(DPPH),2, 2-azino-bis(3-ethylbenzo thiazoline-6-sulfonic acid) diammonium salt (ABTS), potassium persulfate, 2,4,6-tris(2-pyridyl) -striazine (TPTZ), iron (III) chloride hexahydrate, fluorescein sodium salt, 2,2-azobis(2-amidinopropane) dihydrochloride (AAPH), 6-hydroxy-2,5,7,8-tetramethylchromane-2carboxylic acid (trolox)는 Sigma Chemical Co. (USA) 제품을 구입 하여 사용하였다. 사용 효소인 Multifect PR 6L, pepsin, pancreatin은 (주) 비전바이오캠(Sungnam, Korea)에서 구입하 여 사용하였으며, 그 외 사용된 용매 및 시약은 모두 일급 이상 의 등급을 사용하였다.

\section{제주산 마(한라마) 사골 추출물 제조}

본 실험에서 사용된 제주산 마(한라마) 사골 추출과정은 Fig. 1 에 나타내었다. 말 사골의 핏물을 제거하기 위해 $4^{\circ} \mathrm{C}$ 물 에서 12 시간 침수시켜 핏물을 제거하였다. 사골 중량의 10 배 물을 넣고, 30 분간 끓인 후 찬물로 씻어 이물질을 제거하였다. 핏물과 이물질을 제거한 말 사골 중량의 4 배의 물을 다시 가한 후 8시간씩 3회 추출하여 거즈로 여과하였다. 여과액은 동결 건조(EYELA, FDU-1200, Japan)한 후 Folch 용액(Chloroform: Methanol, 2:1, v/v)을 첨가하여 지방제거 하였고 $40^{\circ} \mathrm{C}$ 의 drying oven에서 건조하여 사용하였다. 제주산 마(한라마) 사골 추출분말에 8 배의 물을 가한 후 $80^{\circ} \mathrm{C}$ 에서 1 시간 수화 시킨 후, multifect PR 6L, pepsin, pepsin과 pancreatin 혼합효소 (1:1)을 사골 추출물 중량당 각각 $0.2 \%$ 씩 첨가하여 각각 $\mathrm{pH}$ $8.0,3.0,3.0 ~ 8.0(\mathrm{pH} \mathrm{3.0}$ 에서 2시간 정치 후 $\mathrm{pH}$ 8.0에서 2시간 정치)으로 보정하였고 각각 $60^{\circ} \mathrm{C}, 50^{\circ} \mathrm{C}, 50^{\circ} \mathrm{C}$ 에서 4 시간 동안 분해 하였다. 이를 $3 \mathrm{kDa}$ 의 크기를 기준으로 분리하기 위해 멤브레인 여과 장치 $(3 \mathrm{kDa}$, Millipore, Ireland)를 이용하여 3 $\mathrm{kDa}$ 이상의 고분자 분해물과 $3 \mathrm{kDa}$ 이하의 저분자 분해물로 분리하였으며, 각각 $\mathrm{MP}, \mathrm{PS}, \mathrm{PSPC}$ 로 표기한 후 동결건조하여 $-20^{\circ} \mathrm{C}$ 냉동고에 보관하여 사용하였다.

\section{단백질 함량 측정}

단백질 농도는 Kim 등[12]이 제시한 대로 bovine serum albumin (BSA)를 표준용액으로 사용하였고, bicinchoninic acid (BCA) 단백질 분석 kit (Sigma Chemical Co., USA)를

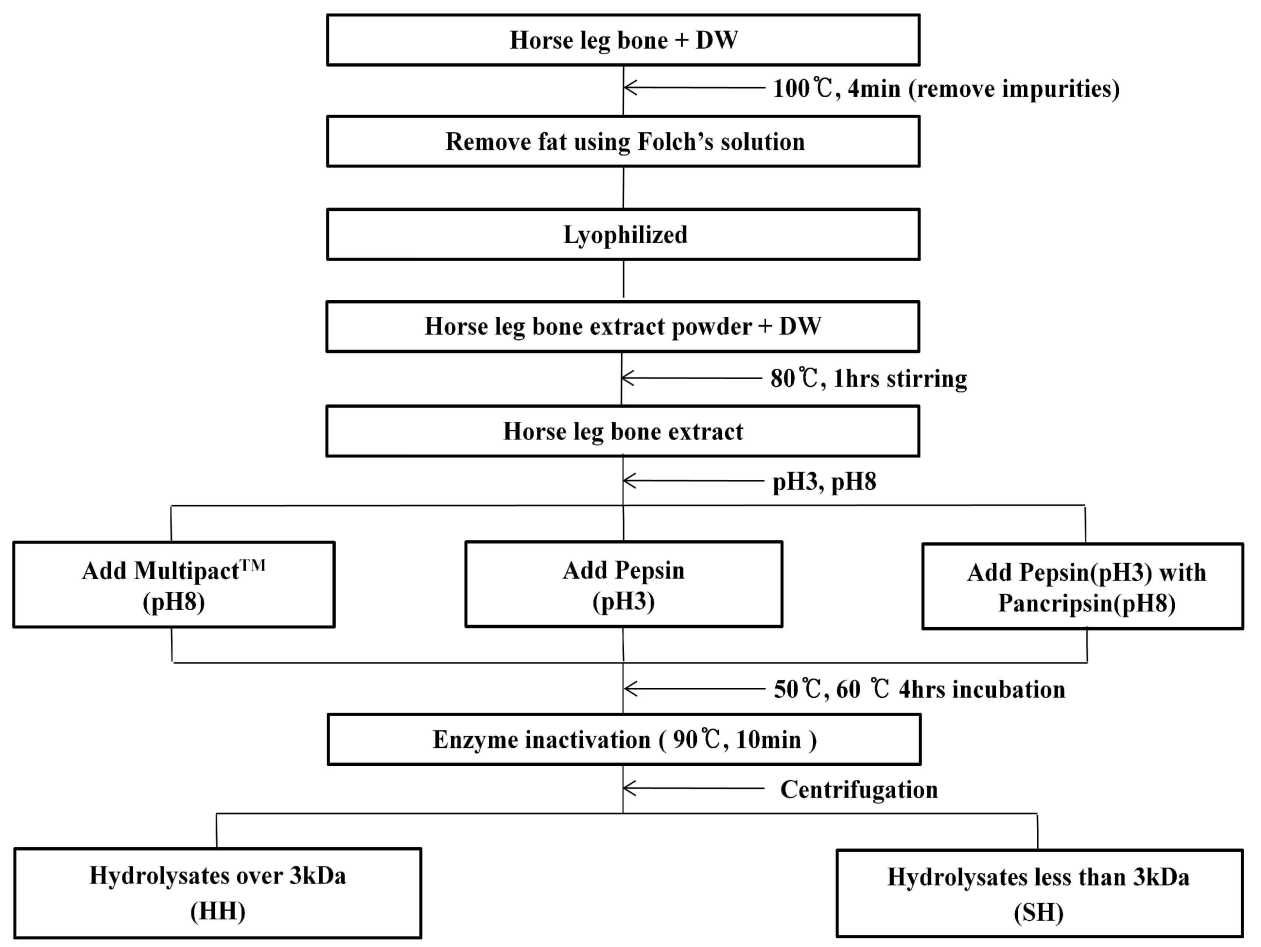

Fig. 1. Preparation procedure of Jeju crossbred horse's leg bone extracts and its enzyme hydrolysates. 
이용하여 측정하였다.

\section{SDS-PAGE 전기영동}

SDS-PAGE는 Laemmli [17]의 방법을 일부 변형하여 이용 하였다. Prosi prestained protein marker (GenDEPOT, USA) 를 사용하여, $5 \%$ stacking gel과 $12 \%$ separating gel을 만들어 사용하였으며 시료는 제주산 마(한라마) 사골 추출물을 분말 화하여 단백질 함량 정량 후, 2X sample buffer와 1:1로 혼합한 후 $100^{\circ} \mathrm{C}$ 에서 5 분간 열처리하여 사용하였다. 전기영동장치 (PageRun, AE-6531, ATTO, Japan)를 이용하여 $100 \mathrm{~V}$ 로 전기 영동 하였으며, $0.25 \%$ Coomassie brilliant blue R-250, 5\% methanol와 $7.5 \%$ acetic acid으로 제조한 염색액을 이용하여 젤을 염색하였고, $7.5 \%$ acetic acid와 $25 \%$ methanol로 만든 탈색액으로 탈색하여 분리된 단백질 밴드를 확인하였다.

\section{$\mathrm{DPPH}$ 라디칼 소거활성 측정}

$\mathrm{DPPH}$ 라디칼 소거능은 Blois [5] 방법을 변형하여 측정하 였다. 농도를 제주산 마(한라마) 사골추출분말 $20 \mathrm{mg} / \mathrm{ml}$ 로 조정한 각 시료 $1 \mathrm{ml}$ 와 $0.2 \mathrm{mM} \mathrm{DPPH}$ solution (in methanol) $1 \mathrm{ml}$ 를 혼합하여 암실에서 30 분간 반응시킨 뒤, microplate reader (SpectraMax M2e, Molecular Devices, USA)을 이용하 여 $517 \mathrm{~nm}$ 에서 흡광도를 측정하였다. 표준물질로 사용한 trolox 농도에 상당하는 $\mathrm{mM}$ trolox equivalent로 계산하여 결과 를 나타내었다.

\section{$\mathrm{ABTS}$ 라디칼 소거 활성 측정}

$\mathrm{ABTS}$ 라디칼 소거능은 Re 등[26]의 방법을 변형하여 다음 과 같이 측정하였다. $7 \mathrm{mM} \mathrm{ABTS} \mathrm{용액과} 2.45 \mathrm{mM}$ potassium persulphate 용액을 혼합하고, $\mathrm{ABTS}^{+}$라디칼을 만들기 위해 실온에서 16 시간 동안 암소 반응시켰다. 라디칼이 생성된 용 액을 $735 \mathrm{~nm}$ 에서 흡광도 값이 $0.700 \pm 0.02$ 가 되도록 희석하여 사용하였다. 시료 또는 표준시약(trolox) $50 \mu 1$ 와 $\mathrm{ABTS}^{+}$용액 $950 \mathrm{\mu l}$ 을 혼합하여 $30^{\circ} \mathrm{C}$ 암실에서 30 분간 반응시킨 뒤, microplate reader (SpectraMax M2e, Molecular Devices, USA)을 이용하여 $735 \mathrm{~nm}$ 에서 흡광도를 측정하였다. 표준물질로 사용 한 trolox 농도에 상당하는 $\mathrm{mM}$ trolox equivalent로 계산하여 결과를 나타내었다.

\section{Ferric reducing/antioxidants power (FRAP)}

FRAP 활성은 시료 중의 항산화 물 질에 의해 $\mathrm{Fe}(\mathrm{III})-\mathrm{TPTZ}$ 가 $\mathrm{Fe}(\Pi)-\mathrm{TPTZ}$ 혼합물로 환원되는 원리에 의한 Benzie와 Strain [4]의 방법으로 측정하였다. 반응용액은 $300 \mathrm{mM}$ acetate buffer (pH 3.6), $40 \mathrm{mM} \mathrm{HCl}$ 에 녹인 $10 \mathrm{mM} \mathrm{TPTZ} \mathrm{(2,4,6-}$ tris(2-pyridyl)-striazine), $20 \mathrm{mM} \mathrm{FeCl} 3.6 \mathrm{H}_{2} \mathrm{O}$ 를 각각 $10: 1: 1$ 의 비율로 섞어 $37^{\circ} \mathrm{C}$ 로 유지하면서 사용하였다. 시료 또는 표준 시약인 trolox $25 \mu 1$ 와 미리 만들어놓은 반응용액 $175 \mu 1$ 를 혼 합하여 암실에서 30 분간 방치한 후, $590 \mathrm{~nm}$ 에서 흡광도를 측 정하였다. 환원력은 표준물질로 사용한 trolox 농도에 상당하 는 $\mathrm{mM}$ trolox equivalent로 나타내었다.

\section{Oxygen radical absorbance capacity (ORAC)}

ORAC 분석은 hydroxyl기나 peroxyl기와 같이 짧은 시간 동안 존재하는 라디칼에 대한 항산화 반응을 검정할 수 있는 방법이다[10]. ORAC은 Gillespie 등[7]의 방법에 따라 다음과 같이 측정하였다. Black 96 well plate에 $25 \mu \mathrm{l}$ 표준시약(trolox) 또는 시료를 넣고, $150 \mu \mathrm{l} \mathrm{fluorescein}(80 \mathrm{nM})$ 을 넣어 혼합한 뒤 $37^{\circ} \mathrm{C}$ incubate에서 15 분 동안 방치하였다. 이 후 $25 \mu \mathrm{l}$ $\mathrm{AAPH}(150 \mathrm{mM})$ 을 넣고 완전하게 혼합한 뒤 fluorescent microplate reader (SpectraMax M2e, Molecular Devices, USA) 를 사용하여 $37^{\circ} \mathrm{C}$ 에서 excitation wavelength $485 \mathrm{~nm}$ 그리고 emission wavelength $520 \mathrm{~nm}$ 에서 60 분 동안 1 분 간격으로 측정하였다. 표준시약(trolox)과 시료의 area under the curve (AUC)를 측정하였으며, 표준시약 농도와 AUC 간의 회귀곡선 을 이용하여 $\mathrm{mM}$ trolox equivalent으로 나타내었다.

\section{통계분석}

본 실험의 모든 결과는 SAS 프로그램(ver. 9.2 Statistics Analytical System)의 General Linear Model을 이용하여 분산 분석하였다. 처리군의 평균값 간의 비교를 위해 Duncan's multiple range test를 이용하여 5\% 수준에서 유의성 검정을 실시하였다.

\section{결과 및 고찰}

제주산 마(한라마) 사골 추출물의 수율과 단백질 함량

제주산 마(한라마) 사골 추출물을 효소분해하여 $3 \mathrm{kDa}$ 보다

큰 분획과 작은 분획을 회수하였으며 각각의 수율을 Table 1에

Tabe 1. Yields of crossbred Jeju horse's leg bone extracts and their hydrolysates (\%)

\begin{tabular}{cccc}
\hline Treatment & Horse leg bone extracts & Hydrolysates over $3 \mathrm{kDa}$ & Hydrolysates less than $3 \mathrm{kDa}$ \\
\hline MP & 100.00 & 70.81 & 10.86 \\
PS & & 89.63 & 3.26 \\
PSPC & 80.87 & 8.00 \\
\hline
\end{tabular}

MP, hydrolysates by multifect PR 6L; PS, hydrolysates by pepsin; PSPC, hydrolysates by combination of pepsin and pancreatin. 
나타내었다. 제주산 마(한라마) 사골 추출물 분말의 수율을 100 으로 하였을 때 효소분해 후 $3 \mathrm{kDa}$ 이상의 크기의 분획 수율은 PS와 PSPC 처리군에서 각각 89.63과 80.87\%을 보였으 나 $\mathrm{MP}$ 처리군에서는 $70.81 \%$ 을 나타내었다. 저분자인 $3 \mathrm{kDa}$ 이하의 분획에서는 각 효소분해에 의한 수율이 각각 3.26 과 $8.00 \%$ 으로 나타나 크게 감소함을 보였다. 반면에 $\mathrm{MP}$ 처리군 에서는 저분자 분획의 수율이 가장 높음을 나타내었다. Kim 등[13]은 돈피에 flavorzyme을 처리하여 얻은 $3 \mathrm{kDa}$ 이하의 저분자 펩타이드 분획의 수율이 $11.73 \%$ 라고 보고하여 본 연구 에서 도출한 $\mathrm{MP}$ 저분자 분획의 수율인 $10.86 \%$ 와는 유사하였 으나 PS와 PSPC 처리구에서는 각각 $3.26,8.00$ 으로 나타나 처 리효소와 조건에 따라 단백질 분해 및 $3 \mathrm{kDa}$ 이하의 저분자 펩타이드 분획의 수율이 달라짐을 나타내었다. 본 연구에서는 multifect PR 6L 효소처리가 가장 높은 수율을 얻을 수 있는 것으로 판단된다. 제주산 마(한라마) 사골 추출물과 분자크기 에 따른 효소 분해물의 단백질함량은 Table 2에 나타내었다. 사골 추출물의 단백질 함량은 $0.6 \mathrm{mg} / \mathrm{ml}$ 로 가장 높았으며 모 든 효소 처리군에서 $3 \mathrm{kDa}$ 이상의 분획이 $3 \mathrm{kDa}$ 이하의 저분 자 분획보다는 유의적으로 높은 단백질 함량을 나타내었다. 특히 PSPC 처리군의 $3 \mathrm{kDa}$ 이하의 분획은 $0.17 \mathrm{mg} / \mathrm{ml}$ 로서 가장 낮은 함량을 나타내었다. 이는 효소에 의해 제주산 마(한 라마) 사골 단백질이 효과적으로 분해되어 저분자화되어 단백 질 함량이 감소함을 나타낸 것으로 판단된다. 단백질의 절단 혹은 분해는 가수분해에 의해 이루어지는데 효소를 처리하여 생성되는 펩타이드 및 저분자 단백질들은 주로 2-20개의 아미 노산으로 구성되어 있으며 분자량의 크기는 $6 \mathrm{kDa}$ 이하의 크 기를 보이며 처리한 효소에 따라 각각의 고유한 기능과 특성 을 가지게 되므로 새로운 생물활성 소재로 이용하기 위해 다 양한 효소가 이용되고 있다 $[9,13,21]$. 본 연구에 이용되었던 효소들의 특성을 살펴보면 multifect PR 6L은 Bacillus licheniformis에서 유래된 것으로 endo-type의 중성-약염기에서 단백 질 분해를 위해 이용된다. Pepsin은 주로 동물의 위장에서 유 래한 것을 이용하며 산성 조건에서 단백질을 분해하는데 이용 되며 특히 단백질의 펩타이드 결합을 endo-type으로 분해하 여 peptide와 amino acid을 생산하는데 이용한다. Pancreatin 은 소나 돼지의 췌장에서 추출한 것으로 중성-약염기성 조건 에서 단백질 펩타이드 결합을 분해하며 amylase와 lipase의

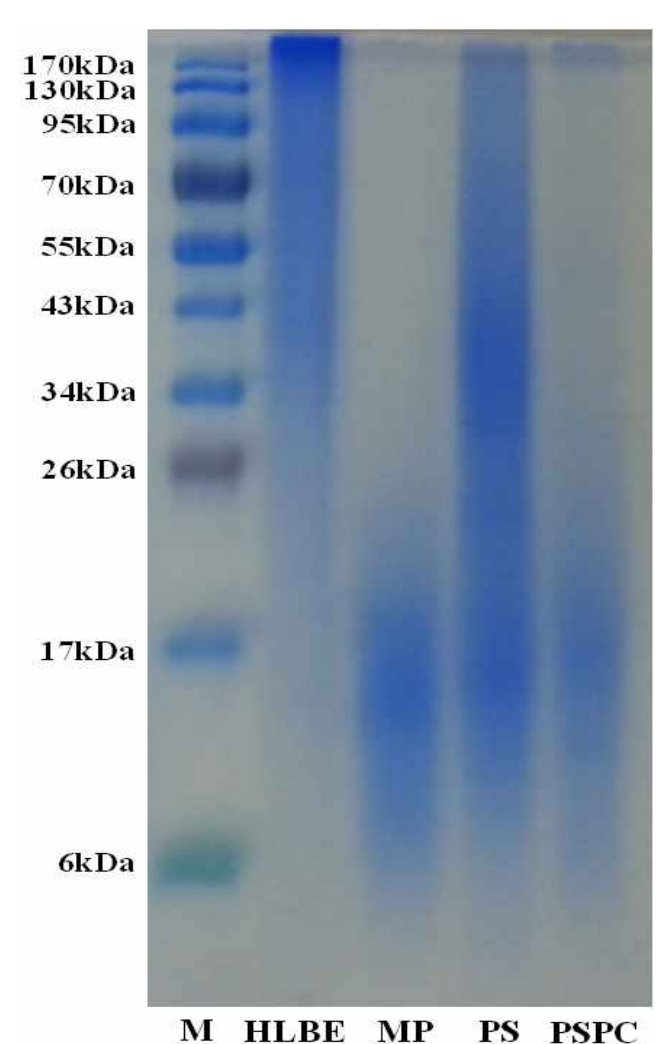

Fig. 2. SDS-Page profile of Jeju crossbred horse's leg bone extracts and enzyme hydrolysates sized over $3 \mathrm{kDa}$. M, protein marker; HLBE, horse leg bone extracts; MP, hydrolysates by multifect PR 6L; PS, hydrolysates by pepsin; PSPC, hydrolysates by combination of pepsin and pancreatin.

기능을 함유하는 효소이다.

제주산 마(한라마) 사골 추출물과 효소분해물의 SDSPAGE

제주산 마(한라마) 사골 추출물을 식품효소인 multifect, pepsin, pepsin과 pancreatin (1:1) 혼합물을 이용하여 분해한 분해물인 MP, PS, PSPC의 SDS-PAGE profile을 Fig. 2에 나타 내었다. 효소분해전의 사골 추출물 자체와 $3 \mathrm{kDa}$ 이상의 크기 의 효소분해물의 SDS-PAGE profile에서 보여주는 바와 같이 효소분해 전 사골 추출물은 정확한 크기의 단백질 밴드가 나

Tabe 2. Protein contents of of crossbred Jeju horse's leg bone extracts and their hydrolysates $(\mathrm{mg} / \mathrm{ml})$

\begin{tabular}{cccc}
\hline Treatment & Horse leg bone extracts & Hydrolysates over $3 \mathrm{kDa}$ & Hydrolysates less than $3 \mathrm{kDa}$ \\
\hline MP & $0.60 \pm 0.004^{\mathrm{Aa}}$ & $0.30 \pm 0.002^{\mathrm{Bb}}$ & $0.21 \pm 0.001^{\mathrm{Ca}}$ \\
PS & $0.60 \pm 0.004^{\mathrm{Aa}}$ & $0.37 \pm 0.011^{\mathrm{Ba}}$ & $0.23 \pm 0.009^{\mathrm{Ca}}$ \\
PSPC & $0.60 \pm 0.004^{\mathrm{Aa}}$ & $0.29 \pm 0.007^{\mathrm{Bb}}$ & $0.17 \pm 0.007^{\mathrm{Cb}}$ \\
\hline
\end{tabular}

All values are mean $\pm \mathrm{SE}$

a-b Mean \pm SE with different letters within a same row differ significantly at $p<0.05$.

A-C Mean \pm SE with different letters within a same column differ significantly at $p<0.05$.

MP, hydrolysates by multifect PR 6L; PS, hydrolysates by pepsin; PSPC, hydrolysates by combination of pepsin and pancreatin. 
타나지는 않았으나 $34 \mathrm{kDa}$ 이상의 거대 단백질로 이루어져 있음을 알 수 있다. 반면에 MP와 PSPC처리구는 거대단백질 보다는 $17 \mathrm{kDa}$ 이하의 단백질 및 펩타이드로 구성되어 있음을 나타내었다. 그러나 PS처리구는 $170 \mathrm{kDa}$ 에서 $6 \mathrm{kDa}$ 에 이르기 까지 넓은 범위의 크기로 분해되었음을 나타내었다.

\section{제주산 마(한라마) 사골 추출물과 분자크기에 따른 효소분 해물의 항산화 활성}

식품내 구성성분의 항산화활성 측정은 식품제품 내 항산화 물질의 함량을 측정하여 산화에 대항하는 능력과 식품의 섭취 후 생체 내부에서 항산화 활성을 갖는지에 대한 정보를 제공 할 수 있다[27, 29]. 화학적 반응식에 의한 항산화 활성 측정법 은 크게 2가지로 나눌 수 있는데 electron transfer (ET)와 hydrogen atom transfer (HAT)에 근거한 방법이다[8]. ET에 근 거한 분석법은 항산화 물질의 활성을 산화제의 환원력을 측정 하는 것으로 반응을 모니터링하기 위한 probe와 반응 종결점 을 나타내는 indicator로서의 역할을 한다. 대표적인 측정방법 에는 trolox equivalent antioxidant capacity (TEAC), the ferric ion reducing antioxidant power (FRAP), 2-2-diphenyl1-picrylhydrazyl radical scavenging capacity (DPPH)이 있다. $\mathrm{HAT}$ 에 근거한 방법은 경쟁적 반응을 측정하는 것으로 항산 화 물질과 기질이 열에 의해 발생한 peroxyl radicals에 대해 경쟁적으로 작용하는 것을 측정한 방법으로 oxygen radical absorbance capacity (ORAC)가 대표적인 예이다[27]. 이들 분 석법을 이용하여 제주산 마(한라마) 사골 추출물과 효소분해 물의 항산화 활성은 다음과 같다.

\section{$\mathrm{DPPH}$ 라디칼 소거활성}

$\mathrm{DPPH}$ 는 보라색을 띄는 비교적 안정한 자유 라디칼로서 항산화제, 방향족 아민류에 의해 전자나 수소를 받아 환원되 어 안정한 분자를 형성하게 되는데 이것은 다양한 천연소재로 부터 항산화 물질을 탐색하는데 많이 이용되고 있으며 $[3,14]$, 비교적 짧은 시간 내에 간단하게 항산화활성을 측정할 수 있
는 장점이 있으나[25] $\mathrm{DPPH}$ 가 $\mathrm{pH}$, 빛, 온도에 매우 민감하게 영향을 받는 단점이 있다. 제주산 마(한라마) 사골 추출물과 효소분해물 분말을 $20 \mathrm{mg} / \mathrm{ml}$ 의 농도로 고정한 후 $\mathrm{DPPH}$ 라 디칼 소거활성 측정 결과는 Fig. 3 에 나타내었다. 소거능은 trolox의 표준물질로 하여 trolox의 항산화효과를 나타내는 농 도 $(\mathrm{mM})$ 와 비교하여 표시하였다. 제주산 마(한라마) 사골추출 물 자체는 $\mathrm{PS}$ 처리군의 $3 \mathrm{kDa}$ 이상의 분획과 함께 가장 낮은 $\mathrm{DPPH}$ 소거능을 보였다( $p<0.05)$. 그러나 사골 추출물을 multifect PR 6L, pepsin, pepsin과 pancreatin 혼합효소(1:1)를 이용 하여 분해한 후 분리한 $3 \mathrm{kDa}$ 이하의 펩타이드는 $0.14 \mathrm{mM}$ trolox equivalent에 해당하는 효과를 나타내어 분자 크기가 3 $\mathrm{kDa}$ 이상 되는 분획보다 강한 $\mathrm{DPPH}$ 라디칼 소거능을 나타내 었다( $p<0.05)$. Kim 등[13]은 flavorzyme으로 분해한 저분자 돼 지껍질 추출물을 $50 \mathrm{mg} / \mathrm{ml}$ 의 농도로 하여 $\mathrm{DPPH}$ 소거능을 측정한 결과 $91.97 \%$ 의 억제율을 보여 $1 \mathrm{mg} / \mathrm{ml}$ 의 비타민 C와 동일한 항산화 효과를 나타내었고 $3 \mathrm{kDa}$ 이상의 분획보다 유 의적으로 높은 라디칼 소거능을 보고하여 동물성 단백질의 효소분해물의 경우 분자량의 크기가 작을 경우 보다 효과적으 로 $\mathrm{DPPH}$ 라디칼을 소거함을 보여 본 연구결과와 유사한 결과 를 제시하였다.

\section{$\mathrm{ABTS}^{+}$라디칼 소거활성}

ABTS radical은 비교적 안정한 자유 라디칼로서, potassium persulfate와의 반응에 의해 생성된 $\mathrm{ABTS}{ }^{+}$이 시료 중의 항산화성 물질에 의해 제거되어 라디칼 특유의 청록색이 탈색 되는 것을 이용하여 항산화력을 측정하는 방법으로 항산화 활성을 측정하는데 많이 이용된다[20, 31]. DPPH와 같은 라디 컬 소거법에 의한 항산화 활성 측정법이라는 점에서 유사하나 화학반응을 거쳐 프리라디컬을 유발시킨 용액에 시료를 넣어 항산화 활성을 측정한다는 점에서 다르며 프리라디컬을 유발 시키는데 시간이 소요되지만 측정 시에는 빠르게 측정이 가능 하며 $\mathrm{pH}$ 변화에 다소 민감하지 않다는 장점이 있다[30]. ABTS 라디칼 소거활성 측정 결과는 Fig. 4 에 나타내었다. 효소분해

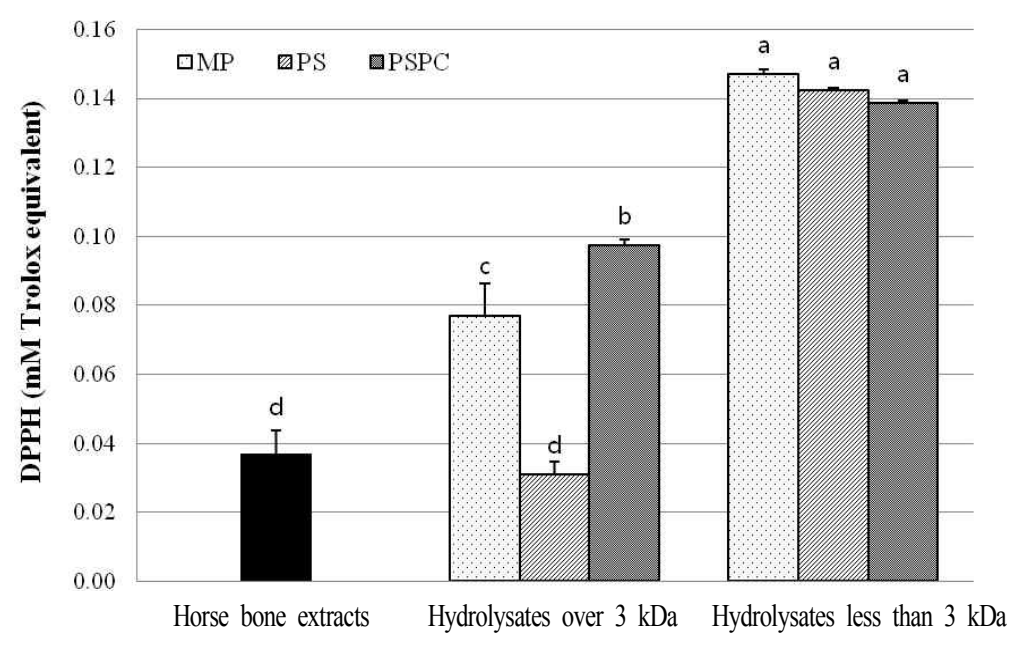

Fig. 3. DPPH radical scavenging activities of Jeju crossbred horse's leg bone extracts and enzyme hydrolysates sized over $3 \mathrm{kDa}$ and less than $3 \mathrm{kDa}$. All values are mean $\pm \mathrm{SE}$. a-d Bars with different superscript differ significantly at $p<0.05$. MP, hydrolysates by multifect PR 6L; PS, hydrolysates by pepsin; PSPC, hydrolysates by combination of pepsin and pancreatin. 


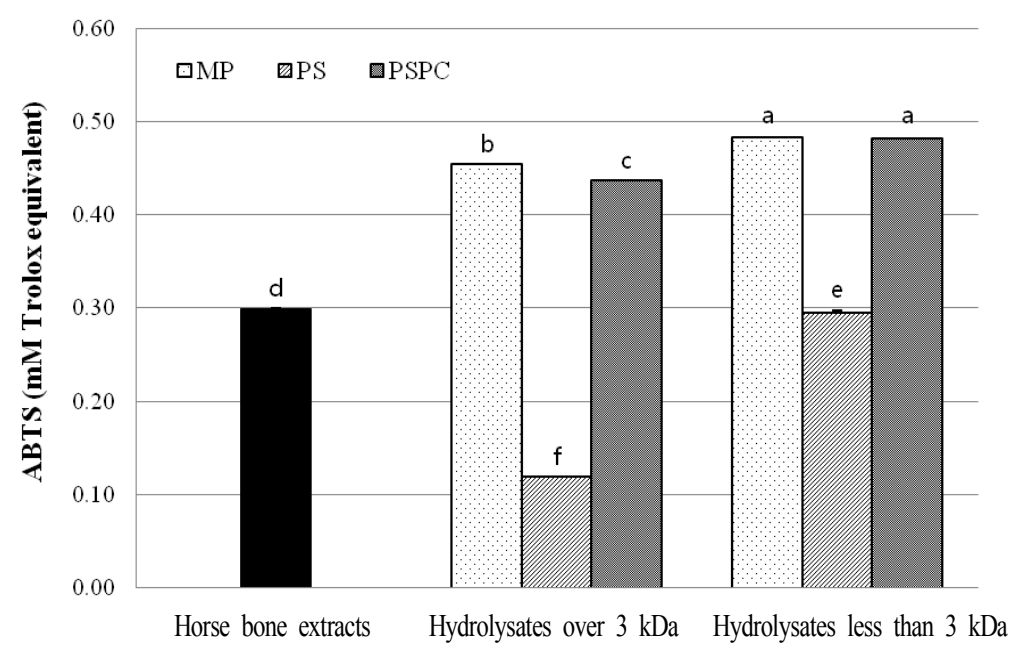

Fig. 4. ABTS radical scavenging activities of Jeju crossbred horse's leg bone extracts and enzyme hydrolysates of sized over $3 \mathrm{kDa}$ and less than $3 \mathrm{kDa}$. All values are mean $\pm \mathrm{SE}$. ${ }^{a-f}$ Bars with different superscript differ significantly at $p<0.05$. MP, hydrolysates by multifect PR 6L; PS, hydrolysates by pepsin; PSPC, hydrolysates by combination of pepsin and pancreatin.

하지 않은 말 사골 추출물은 $0.30 \mathrm{mM}$ trolox에 해당하는 $\mathrm{ABTS}$ 라디칼 소거능을 보였으나 $\mathrm{MP}$ 와 $\mathrm{PSPC}$ 처리군의 저분자 분획 에서 유의적으로 높은 ABTS 라디칼 소거능을 나타내었다 $(p<0.05)$. 흥미롭게도 pepsin을 단독으로 처리하여 분해한 제 주산 마(한라마) 사골 추출물은 분해되기 전 보다도 ABTS 소 거능이 낮은 것으로 보여 효소분해에 의해 항산화 효과가 증 가하지 않음을 나타내었다 $(p<0.05)$.

\section{Ferric reducing antioxidants power (FRAP)}

$\mathrm{FRAP}$ 은 항산화 활성을 측정하는 간단한 방법이다. 이 방법 은 혈중 항산화 효과를 측정하기 위한 방법으로 이용되었으나 현재는 식품성분의 항산화력을 측정하기 위해 자주 이용되는 방법이다[11]. 전자를 제공하는 항산화 물질에 의해 무색의 산 화된 $\mathrm{Fe}^{+3}$ 가 $\mathrm{Fe}^{+2}$-tripyridyltriazine 성분으로 환원되면서 발생 하는 푸른색을 측정하는 방법으로 라디컬 소거 메카니즘과는 다른 환원력 측정을 통한 측정법이다[30]. FRAP 효과는 Fig. 5 에 나타내었다. DPPH 소거능과 매우 유사한 결과를 나타내 었으며 pepsin을 이용하여 분리한 $3 \mathrm{kDa}$ 이하의 분획에서 유 의적으로 높은 항산화 활성을 나타내었다. 반면에 $3 \mathrm{kDa}$ 이상
의 분획에서는 효소분해전의 사골 추출물보다도 낮은 FRAP 값을 나타내었다 $(p<0.05)$.

\section{Oxygen radical absorbance capacity (ORAC)}

ORAC assay는 기존 여러 항산화 활성 측정방법에 비해 반응 감도가 예민하여 정확도가 높은 것으로 알려져 있다[23, 24]. ORAC의 측정 결과는 Fig. 6에 나타내었으며, 표준시약으 로 비타민 $\mathrm{E}$ 수용성 유도체인 trolox를 사용하여 그 효과를 비교하였다. 각 효소분해물은 분자량이 작을수록 더 강한 ORAC값을 나타내었다. 특히 $3 \mathrm{kDa}$ 이하의 크기의 분획이 분해 전 제주산 마(한라마) 사골 추출물보다 유의적으로 높은 ORAC효과를 보였으나 pepsin 분해물 $(0.12 \mathrm{mM}$ trolox equivalent)은 저분자 크기에서도 $\mathrm{MP}(0.20 \mathrm{mM}$ trolox equivalent) 와 PSPC (0.17 mM trolox equivalent)처리군 보다 유의적으로 가장 낮은 활성을 나타내었다. Kim 등[13]은 돼지껍질 추출물 을 flavorzyme으로 분해하여 얻는 $3 \mathrm{kDa}$ 이하의 분획물의 ORAC 활성을 측정한 결과 $1 \mathrm{mg} / \mathrm{ml}$ 의 농도에서 $140 \mathrm{uM}$ trolox equivalent의 활성을 나타내었음을 보였다. 또한 본 연구 팀의 선행연구결과에 의하면 말과의 한 종류인 당나귀 사골과

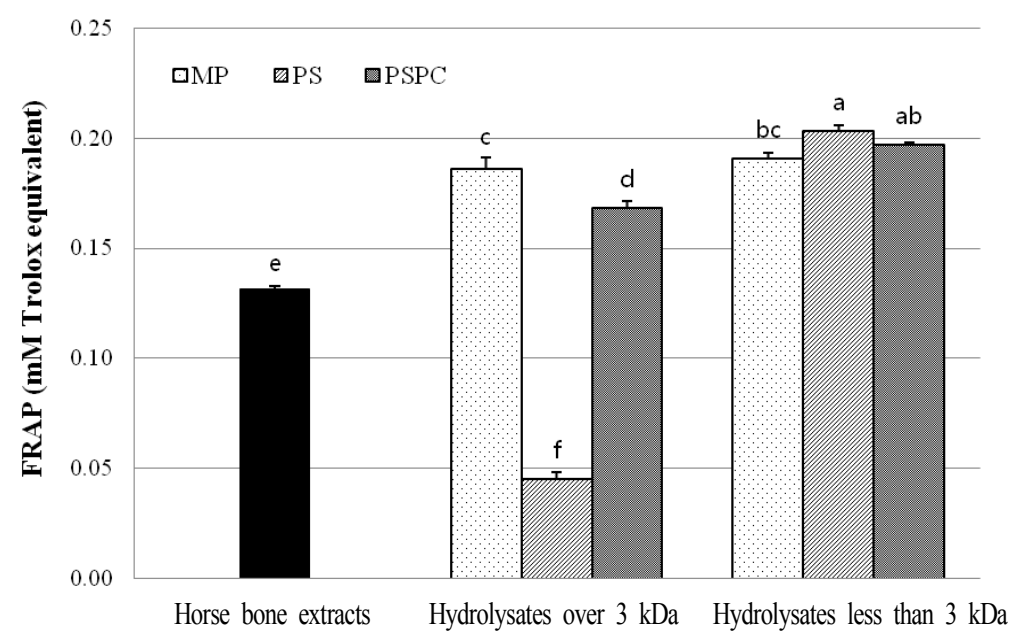

Fig. 5. FRAP of horse leg bone extracts and enzyme hydrolysates of Jeju crossbred horse's leg bone extracts and enzyme hydrolysates of sized over $3 \mathrm{kDa}$ and less than $3 \mathrm{kDa}$. All values are mean $\pm \mathrm{SE}$. ${ }^{\mathrm{a}-\mathrm{f}}$ Bars with different superscript differ significantly at $p<0.05$. MP, hydrolysates by multifect PR 6L; PS, hydrolysates by pepsin; PSPC, hydrolysates by combination of pepsin and pancreatin. 


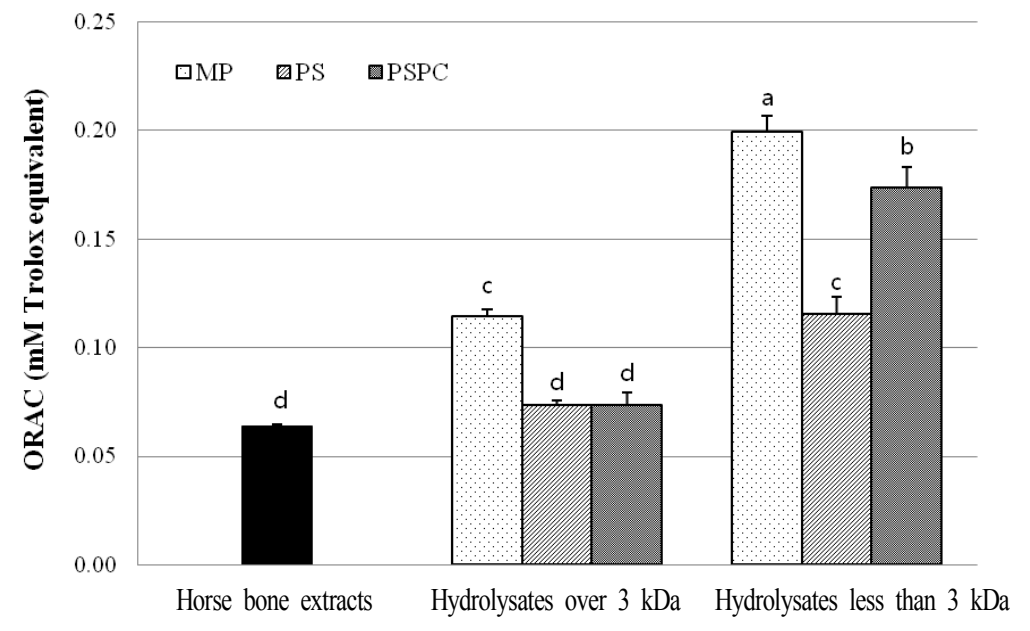

Fig. 6. ORAC of horse leg bone extracts and enzyme hydrolysates of Jeju crossbred horse's leg bone extracts and enzyme hydrolysates of sized over $3 \mathrm{kDa}$ and less than $3 \mathrm{kDa}$. All values are means $\pm \mathrm{SE}$. ${ }^{\mathrm{a}-\mathrm{d}}$ Bars with different superscript differ significantly at $p \propto 0.05$. MP, hydrolysates by multifect PR 6L; PS, hydrolysates by pepsin; PSPC, hydrolysates by combination of pepsin and pancreatin.

껍질 추출물의 ORAC 활성은 농도의존적으로 증가하였고 10 $\mathrm{mg} / \mathrm{ml}$ 의 농도에서 $132.53 \mathrm{uM}$ trolox equivalent을 보였음을 확인하였다[12]. 반면에 본 연구결과 제주산 마(한라마) 사골 효소분해물을 $1 \mathrm{mg} / \mathrm{ml}$ 의 농도로 처리시 $\mathrm{MP}$ 처리군에서 0.20 $\mathrm{mM}$ trolox와 같은 항산화 효과를 보여 돼지껍질과 당나귀 사 골 추출물보다 말 사골 추출물의 ORAC 활성이 우수한 것으로 판단된다.

\section{감사의 글}

본 논문은 농촌진흥청 공동연구사업(과제번호: PJ009417012013)의 지원에 의해 이루어진 것으로 이에 감사드 립니다.

\section{References}

1. Ames, B. N. 1983. Dietary carcinogens and anticarcinogens. Oxygen radicals and degenerative diseases. Science 221, 1256-1264.

2. Ames, B. N., Shigenaga, M. K. and Hagen, T. M. 1993. Oxidants, antioxidants, and the degenerative diseases of aging. Proc Natl Acad Sci USA 90, 7915-7922.

3. Aoshima, H., Tsunoue, H., Koda, H. and Kiso, Y. 2004. Aging of whiskey increases 1,1-diphenyl-2-picrylhydrazyl radical scavenging activity. J Agric Food Chem 52, 5240-5244.

4. Benzie, I. F. and Strain, J. J. 1996. The ferric reducing ability of plasma (FRAP) as a measure of "antioxidant power": The FRAP assay. Anal Biochem 239, 70-76.

5. Blois, M. S. 1958. Antioxidant determination by the use of a stable free radical. Nature 181, 1199-1200.

6. Chang, D. J., Yang, K. C., Kim, J. K., Kang, B. K., Choi, H. S. and Son, C. H. 1991. Studies on the plasma progesterone concentration for pregnancy diagnosis in Che-ju native mare. Korean J Vet Res 31, 529-534.

7. Gillespie, K. M., Chae, J. M. and Ainsworth, E. A. 2007. Rapid measurement of total antioxidant capacity in plants.
Nature Protocols 2, 867-870.

8. Huang, D., Ou, B. and Prior, R. L. 2005. The chemistry behind antioxidant capacity assays. I Agric Food Chem 53, 1841-1856.

9. Jang, A. and Lee, M. 2005. Purification and identification of angiotensin converting enzyme inhibitory peptides from beef hydrolysates. Meat Sci 69, 653-661.

10. Joseph, R. 2004. Comparing antioxidant values with the ORAC method. Altern Complement Ther 10, 167-170.

11. Katalinić, V., Milos, M., Modun, D., Musić, I. and Boban, M. 2004. Antioxidant effectiveness of selected wines in comparison with (+)-catechin. Food Chem 86, 593-600.

12. Kim, D., Chae, H. S., Kim, N. Y. and Jang, A. 2013. Anti-oxidative activity and the protective effect of donkey's bone and skin extracts on SK-N-SH cells. J Life Sci 23, 1019-1024.

13. Kim, D., Park, K. M., Ha, G., Jung, J. R., Chang, O., Ham, J. S., Jeong, S. G., Park, B. Y., Song, J. and Jang, A. 2013. Anti-oxidative and neuroprotective activities of pig skin gelatin hydrolysates. Korean J Food Sci An 33, 258-267.

14. Kim, H. K., Kim, Y. E., Do, J. R., Lee, Y. C. and Lee, B. Y. 1995. Antioxidative activity and physiological activity of some Korean medicinal plants. Korean J Food Sci Technol 27, 80-85.

15. Kim, N. Y., Han, S. H., Lee, S. S, Lee, C. E., Park, N. G., Ko, M. S. and Yang, Y. H. 2011. Relationship between MC1R and ASIP genotypes and basic coat colors in Jeju horses. J Anim Sci Technol 53, 107-111.

16. Kim, Y. B., Jeon, K. H., Rho, J. H. and Kang, S. N. 2005. Physicochemiacl properties of loin and rump in the native horse meat from Jeju. Korean J Food Sci An 25, 365-372.

17. Laemmli, U. K. 1970. Cleavage of structural proteins during the assembly of the head of bacteriophage T4. Nature 227, 680-685.

18. Lee, C. E., Seong, P. N., Oh, W. Y. and Kim, K. I. 2005. Effects of castration on growth and meat quality in finishing male Jeju horses. J Anim Sci Technol Korean 47, 391-396.

19. Lee, S., Choi, H., Son, J., Jeong, J., Kim, Y., Kang, D., Park, S., Kang, S. and Leem, K. 2009. Effects of horse bone powder extract on longitudinal bone growth in adolescent male rats. 
Korean J Herbology 24, 69-77.

20. Li, H., Choi, Y. M., Lee, J. S., Park, J. S., Yeon, K. S. and Han, C. D. 2007. Drying and antioxidant characteristics of the shiitake (Lentinusedodes) mushroom in a conveyer-type far-infrared dryer. J Korean Soc Food Sci Nutr 36, 250-254.

21. Nam, H. S. 1999. Market tendency and development of physiological active peptide. Korean J Food Ind Nutr 4, 17-19.

22. Park, S. S., Lee, H. J., Yoon, W. J., Kang, G. J., Yang, E. J., Kim, H. S., Choo, C. S., Kang, H. K. and Yoo, E. S. 2010. Effects of horse bone extracts on the induced postmenopausal osteoporosis in rats. Korean J Pharmacogn 41, 204-209.

23. Prior, R. L., Hoang, H., Gu, L. Wu, X. Bacchiocca, M. Howard, L., Hampsch-Woodill, M., Huang, D., Ou, B. and Jacob, R. 2003. Assays for hydrophilic and lipophilic antioxidant capacity (oxygen radical absorbance capacity (ORAC) of plasma and other biological and food samples. J Agr Food Chem 51, 3273-3279.

24. Prior, R. L., Wu, X. and Schaich, K. 2005. Standardized method for the determination of antioxidant capacity and phenolics in foods and dietary supplements. J Agr Food Chem 53, 4290-4302.

25. Que, F., Mao, L., Zhu, C. and Xie, G. 2006. Antioxidant properties of Chinese yellow wine, its concentrate and volatiles. LWT-Food Sci Technol 39, 111-117.

26. Re, R., Pellegrini, N., Proteggente, A., Pannala, A., Yang, M. and Rice-Evans, C. 1999. Antioxidant activity applying and improved ABTS radical action decolorization assay. Free Radical Biol Med 26, 1231-1237.

27. Sarmadi, B. H. and Ismail, A. 2010. Antioxidative peptides from food proteins: A review. Peptides 31, 1949-1956.

28. Seong, P. N., Lee, C. E., Park, B. Y., Hah, K. H. and Ko, M. S. 2006. Meat quality and sensory characteristics in longissimus muscle of Jeju horse as influenced by aging. J Anim Sci Technol Korean 48, 287-292.

29. Serrano, J., Go ni I. and Saura-Calixto, F. 2007. Food antioxidant capacity determined by chemical methods may underestimate the physiological antioxidant capacity. Food Res Int 40, 15-21.

30. Yoo, K. M., Kim, D. O. and Lee, C. Y. 2007. Evaluation of different methods of antioxidant measurement. Food Sci Biotechnol 16, 177-182.

31. Yook, H. S., Kim, K. H. and Jang, S. A. 2010. Quality characteristics of grapepomace with different drying methods. $J$ Korean Soc Food Sci Nutr 39, 1353-1358.

초록 : 제주 재래마와 더러브렛종과의 교잡종인 한라마 사골추출물과 효소분해물의 항산화 효과

김동욱 $\cdot$ 박재인 ${ }^{1}$ - 채현석 ${ }^{2} \cdot$ 김영붕 $^{3} \cdot$ 장애라 ${ }^{1}$

('강원대학교 동물식품응용과학과, ${ }^{2}$ 국립축산과학원, ${ }^{3}$ 한국식품연구원)

본 연구는 제주 재래마와 더러브렛(Thoroughbred)종 교잡종인 제주산 마(한라마) 사골 추출분말(HLBE)과 효 소분해물의 항산화 효과를 DPPH, ABTS 라디칼 소거능, FRAP, ORAC 방법을 이용하여 확인하기 위해 실시하였 다. 말 사골 추출물은 열수로 8 시간씩 3 회 추출하여 혼합한 후 동결 건조하여 분말로 이용하였다. 동결 건조된 말 사골 추출물은 식품효소인 multifect PR 6L (MP), pepsin (PS), pepsin+ pancreatin 혼합효소(1:1, PSPC)를 첨가 하고 4 시간 동안 각 효소의 최적활성 온도인 $60,50,50^{\circ} \mathrm{C}$ 에서 분해하였다. 분해 후 $3 \mathrm{kDa}$ 이상의 분획과 이하의 분획으로 분리하였다. 말 사골추출물의 수율을 $100 \%$ 으로 고정하였을 때 각 효소에 의해 분해되어 분리한 $3 \mathrm{kDa}$ 이상의 크기의 분획의 수율은 각각 $10.86 \%, 3.26 \%, 8.00 \%$ 이었다. 단백질 함량은 말 사골 추출물보다 $3 \mathrm{kDa}$ 이하의 저분자 분획에서 유의적으로 감소하였다. $\mathrm{MP}$ 와 $\mathrm{PSPC}$ 처리군의 $3 \mathrm{kDa}$ 이하의 저분자 분획은 말 사골추출물과 3 $\mathrm{kDa}$ 이상의 효소분해물에 비해 유의적으로 높은 $\mathrm{DPPH}$ 와 $\mathrm{ABTS}$ 라디칼 소거능과 ORAC 활성을 나타내었다. 그 러나 $\mathrm{PS}$ 처리군 내 $3 \mathrm{kDa}$ 이하의 저분자 분획은 $\mathrm{MP}$ 처리군 보다 유의적으로 높은 $\mathrm{FRAP}$ 활성을 나타내었다. 이러 한 결과는 말 사골 추출물 자체 보다는 효소를 이용하여 분리한 $3 \mathrm{kDa}$ 이하의 저분자 펩타이드가 더욱 강한 항산 화 효과를 갖는 것을 제시하는 것으로 특히 pepsin에 의해 생성된 저분자펩타이드 보다는 multifect와 pep$\sin +$ pancreatin 혼합효소(1:1)에 의해 생성된 분해물이 더욱 높은 항산화 효과를 나타내었다. 그러므로 말 사골추 출물을 multifect와 pepsintpancreatin 혼합효소(1:1)를 이용하여 효소 분해하여 얻은 $3 \mathrm{kDa}$ 이하의 저분자 펩타이 드 분획은 항산화제로서 식품산업계에서 이용될 수 있을 것으로 예상되며 이를 뒷받침하기 위해 in vivo 테스트가 추후 진행되어야 할 것으로 판단된다. 